\title{
The Art Market in the European Union
}

\author{
Anna Lucińska
}

Published online: 16 December 2014

C The Author(s) 2014. This article is published with open access at Springerlink.com

\begin{abstract}
There is a broad discussion in the literature concerning various aspects of art as an investment, where the return on art assets has been of special interest, but so far there is little achievement in the analysis of the performance of art markets in various countries of the European Union. The objective of this article is to make an attempt to fill the gap in the research of the Polish emerging art market as seen from this perspective. The objective is achieved by calculating quarterly hedonic price indices and rates of return using 1708 auction records covering the sale of paintings by 30 painters obtained from Polish art websites at www.artinfo.pl and www.agraart.pl. The estimated price index enables us to analyze the relationship of this index and the rate of return with European (i.e. French and British) art indices and rates of return. This study shows that returns on Polish art averaged 5.51 \% in nominal terms over the period 2008-2012 with a standard deviation of $8.34 \%$. It shows that over this period the art market in Poland proved more profitable and more variable in comparison with European art markets.
\end{abstract}

Keywords Hedonic price index $\cdot$ Rate of return · Art market

JEL Classification $\mathrm{G} 20 \cdot \mathrm{G} 30$

\section{Introduction}

Art has been an optimal investment opportunity for over forty years [Sokołowska; $2012 ; 159-175]$. One of the crucial questions in analyzing the investment opportunities is whether assets such as works of art appearing on the Polish auction market should be the subject of our concern during the turbulences that characterize contemporary financial markets. Another question is whether the artworks and their prices and rates of return, as alternative investment features, can be taken into consideration.

\footnotetext{
A. Lucińska $(\bowtie)$

Department of Industry Politics and Capital Market / Faculty of Economics and Sociology, University of Łódź, 90-214 Łódźul. Rewolucji 1905 r. nr 41/43, Poland

e-mail: aleksoc@wp.pl
} 
As there is growing interest in the economics of culture and art, many theoretical publications on the subject appeared (Hausner, Karwińska, Purchla 2013); (Forte, Mantovani 2004); (Throsby 2010); (Towse 2011) among others. Moreover, there is a broad discussion in the world literature on various aspects of art as an investment, focusing on methods of calculating indices of art markets that are necessary in defining the return on investment in art. The objective of this article is to fill the gap in research on the Polish emerging art market.

There are Polish artists who have achieved international recognition and financial appreciation, and whose works exceeded the price level of \$1 million: Tamara de Lempicka (who is a prominent member of a small group of global female artists; the most valuable painting by Lempicka ever sold publicly reached $\$ 8.5$ million at Sotheby's NY in 2011), Henryk Siemiradzki (above \$2 million at Sotheby's NY in 2011), Roman Opalka (\$1.2 million at Christie's London 2010) and Piotr Uklański (\$1 million at Philips London in 2006) [Gajewski, Potocki; 2013; 6-8]. However, their works are rarely auctioned in Poland, which has developed its separate art market segment. The domestic Polish auction market trades the artworks of painters who have not managed to get on the global market yet. But, as the source of paintings proved quite effective by revealing talented and appreciated painters, there is a need to show the returns on investment in artworks within the Polish art market and to compare it with art markets in other EU countries.

There has been neither a hedonic price study nor any other studies on Polish painters. The objective of this study is to construct a quarterly Polish art market index and to answer the question on the rates of return on this market. It will enable us to discuss the relationship of Polish art indices and returns with the indices of European (i.e. French and British) art indices and returns based on data published on the website www.artprice.com.

\section{Literature on Art Indices}

There are different methodologies applied to calculate an art index: the average price, geometric mean estimator, the repeat sales method, etc. The hedonic price method is based on the hedonic price regression model to construct a price index. The most important advantage of the hedonic price method is that it needs neither to select items of the same quality nor to reject artworks that were sold only once in a sample period. This provides a huge increase in the sample size available for research. The number of authors using auction data to analyze the art market is rapidly growing. There are many researchers seeking the best way to define the price index. Some opinions seem to be worth mentioning.

The set of variables chosen for the hedonic regression model is diversified but there are some variables used in most of the cases studied, i.e. date of sale, width and height or surface, technique (medium used such as oil, watercolor, acrylic, tempera, etc. and support such as canvas, desk, cardboard etc.), auction house, painter and signature. Other variables reflecting attributes of paintings, painters and 
the auction sale are the subject of researcher's choice and appear in individual cases, which has been shown in Table 1 .

There is conflicting evidence about the returns of art investments. Kraeussl and Schellart (2007) find that returns on German paintings were remarkably low while Kraeussl and Logher (2010) claim that art from India is extremely profitable with the return of $42.2 \%$ per year.

\section{Methodology}

The hedonic price index method is used to estimate the implicit prices for artistic characteristics from auction prices. In this approach the assumption is made that hedonic prices of artworks are implicit prices of a set of different attributes that bear some quality. It relates transaction prices to a wide range of value-determining characteristics and year effects. These characteristics are included in the regression model:

$$
\ln p_{k t}=\alpha_{0}+\sum_{m=1}^{M} \alpha_{m} X_{m k t}+\sum_{t=1}^{T} \beta_{t} Y_{t}+\xi_{k t}
$$

where $\ln p_{k t}$ is the natural logarithm of the price of artwork $k(k=1,2, \ldots K)$ sold in the quarter and year $t(t=1,2, \ldots T), \alpha_{0}$ is the intercept, $X_{m k t}$ is the characteristic $m(m=$ $1,2, \ldots M)$ of painting $k$ sold at the time $t$ (explanatory variables: the name of the painter, living status, medium, surface $\left(\mathrm{m}^{2}\right)$, auction house), $\alpha_{m}$ and $\beta_{t}$ are the parameter estimates, $Y_{t}$ is a dummy variable which takes the value of " 1 " if the sales in the year and quarter $t$ occur, and " 0 " elsewhere, $\xi_{k t}$ is random error.

The determinants of price, i.e. explanatory variables in the hedonic pricing regression, include personal characteristics of the artist, physical attributes of an artwork, and features of the auction at which the sale took place. Most of them take the form of a dummy variable. In all cases, one dummy was omitted to avoid collinearity. The first variable in the set of personal characteristics is the artist (i.e. the name of an artist), which is the factor that bears the reputation and the quality of the artist and is one of the most important factors affecting the price of the painting. Dummy variables $(A X E, B O Z \ldots Z A K)$ are applied to link each artist with his or her work, with Vlastimil Hofman as a reference category. The living status of an artist $(D T H)$ is also a dummy variable taking a value of " 1 ", if the artist was deceased at the date of the auction and " 0 " if not. It is expected that the price of an artwork is likely to increase once the painter has died (the sign of the coefficient is expected to be greater than zero).

Variables representing the physical attributes of an artwork comprise the medium and surface (in $\mathrm{m}^{2}$ ). The set of dummy variables identifying the medium of the work includes WATERCOLOR and OIL, the reference category is all other media (acrylic, gouache, pastel, tempera, mixed media, etc.). OIL is the most common medium and is expected to bear a higher quality and thus a higher price. Another variable related to a physical feature of the painting is $S U R F A C E$. It is expected to obtain a positive relationship when the price is 
Table 1 Explanatory variables in the hedonic regression models - the review of the literature

$\begin{array}{lllllllllllllllllllll}\text { A } & \text { B } & \text { C } & \text { D } & \text { E } & \text { F } & G & \text { H } & \text { I } & \text { J } & \text { K } & \text { L } & \text { M } & \text { N } & \text { O } & \text { P } & \text { Q } & \text { R } & \text { S } & \text { T }\end{array}$

Painter characteristics

artist

African American / white American status

painter's year of birth

painter's year of death

living status

country of artist's birth

nationality

word count of articles published by Grove Art

Online

presence in the classic art history texts

presence at the prestigious exhibition

price range

average price

works sold in a calendar year

works sold in a calendar year ${ }^{2}$

school

Artwork characteristics

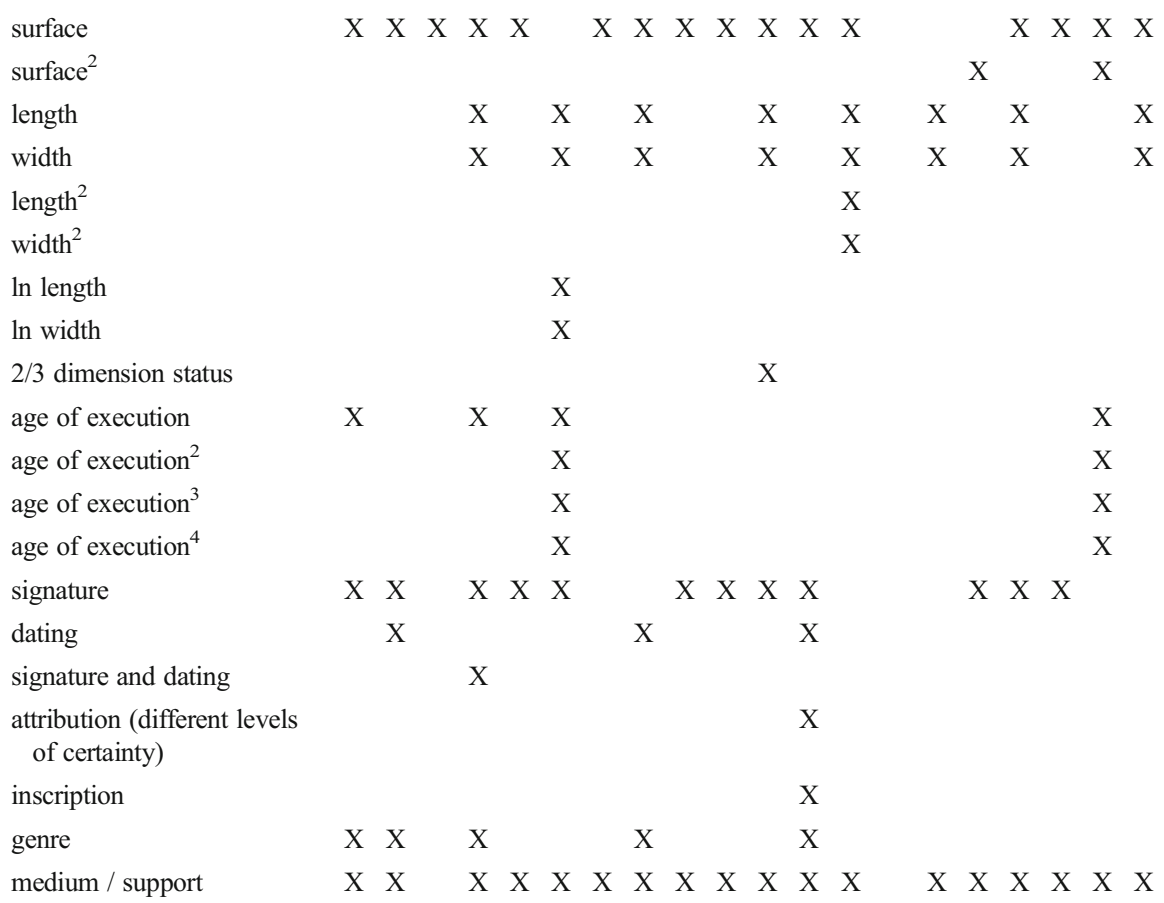

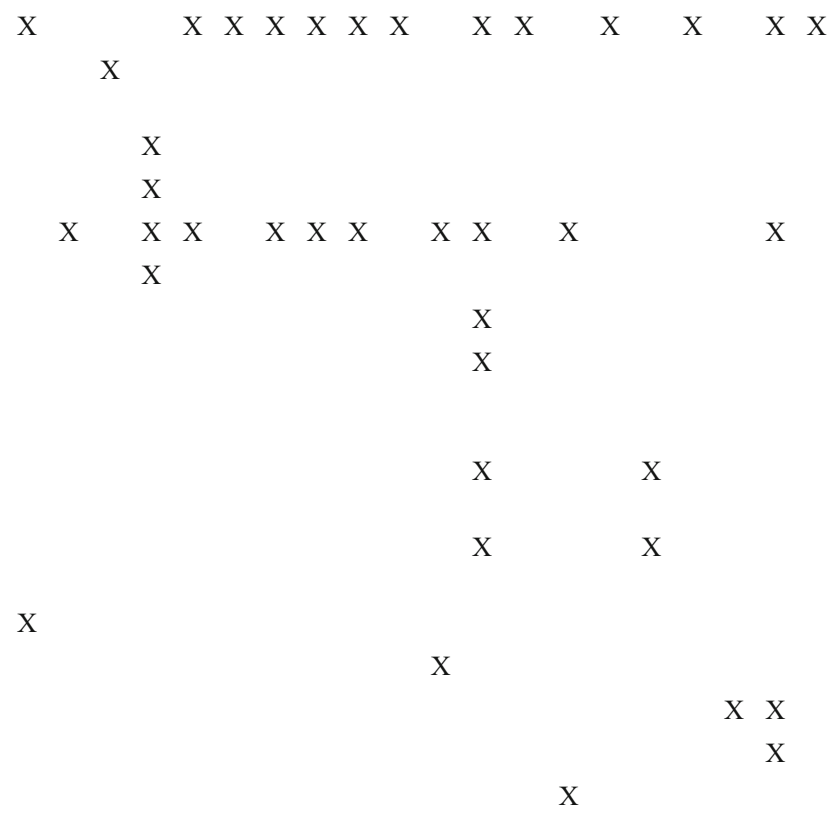


Table 1 (continued)

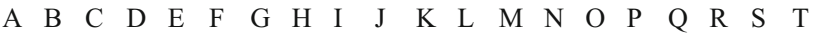

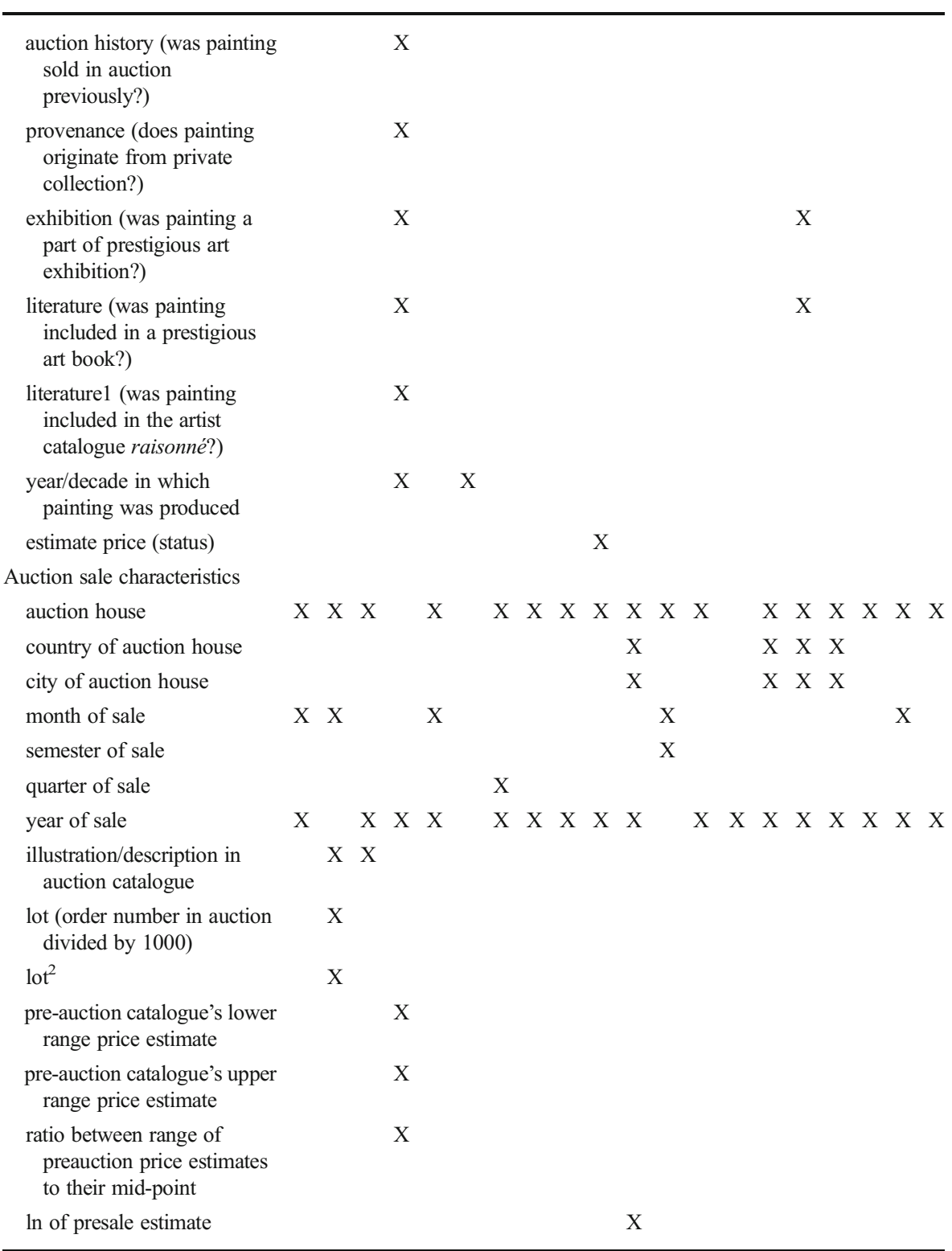

Source: My own study

Where: A - Agnello and Pierce, 1996; B - Agnello 2002; C - Agnello and Xu, 2008; D - Barbosa and Campos, 2008; E - Dürr 2010; F - Edwards 2004; G - Higgs 2012; H - Hodgson 2011; I - Kräussl and Elsland, 2008; J - Kraeussl and Logher, 2010; K - Kraeussl and Schellart, 2007; L - Renneboog and Spaenjers, 2013; M - Chanel et. al., 1996; N - Buelens and Ginsburgh, 1993; O - De la Barre et. al., 1994; P - Czujack 1997; Q - Renneboog and van Houtte, 2002; R - Biey and Zanola, 2005; S - Worthington and Higgs, 2006; T Hodgson and Vorkink, 2004 
regressed against the SURFACE. A large-sized painting is expected to influence the price positively.

The last series of explanatory variables refer to sales characteristics. Dummy variables identify the auction house of the sale such as Agra-Art (AHAGRA), Desa (AHDESA), Polswiss Art (AHPOLSWISS) and Rempex (AHREMPEX). They are the largest Polish auction houses and are likely to influence the price positively. The reference category is all other auction houses (Desa Unicum, Okna Sztuki, Ostoya, and Rynek Sztuki, among others). The second group of sales characteristics identifies the year and quarter of sale, and contains 24 quarterly dummy variables from the years 2007-2012 with 2007 quarter one (2007Q1) as the reference category.

Based on the estimated regression coefficients in the model, a hedonic price index is built with the application of the formula [Kräussl, Elsland; 2008; p. 6]:

$$
\text { index }=\frac{\prod_{i=1}^{n}\left(P_{i, t+1}\right)^{1 / n} / \prod_{i=1}^{m}\left(P_{i, t}\right)^{1 / m}}{\text { hedonic quality adjustment }}
$$

This equation indicates that the index is a ratio of geometric means of painting prices in quarters $t+1$ to $t$, divided by a hedonic quality adjustment. Note that the number of artworks sold in quarters $t$ and $t+1$ is not equal, thus there are different superscripts $m$ and $n$. The hedonic quality adjustment is given by the following formula [Triplett; 2006; p. 63]:

$$
\text { hedonic qualityadjustment }=\exp \left[\sum_{j=1}^{z} \alpha_{j}\left(\sum_{i=1}^{n} \frac{X_{i j, t+1}}{n}-\sum_{i=1}^{m} \frac{X_{i j, t}}{m}\right)\right]
$$

The hedonic quality adjustment is an index itself, a base exponent of mean changes in the characteristics of paintings sold in quarters $t+1$ and $t$, weighted with their implicit prices ( $\alpha$ coefficients from regression Eq. 1$)$.

Having quarterly art indices index $(t=1,2,3,4)$, the average rates of change for each year were calculated for the British, French and Polish art markets. The formula for average annual change represents geometric mean of chain quarter indices:

$$
G M Y=\sqrt[4]{\prod_{t=1}^{4}} \text { index }_{t}
$$

Finally, the rate of return for each year equals:

$$
G Y=(G M Y-1) \times 100
$$

Similarly, an average change for the whole investigated period is given by the formula:

$$
G M P=\sqrt[24]{\prod_{t=1}^{24}} \text { index }_{t}
$$

and the rate of return for this period uses the formula:

$$
G P=(G M P-1) \times 100
$$




\section{Data Sample and Descriptive Statistics}

The study sample covers auction records obtained from Polish art websites at www. artinfo.pl and www.agraart.pl. Painters were qualified for the study sample based on the criterion of their influence on the art market, which was measured by the product of the number and value of works sold (Lucinska 2011, p. 244). In effect, the study sample consists of 1708 auction records covering the sale of artworks by 30 painters. The data cover the period from 2007 quarter one to 2012 quarter four. Each auction record contains data describing: (a) personal characteristics of the artist, i.e. the name of the artist with dates of birth and death (if any), (b) physical attributes of an artwork, i.e. the title of the artwork, medium, length and width (in mm.), signature and dating (if any), and (c) sales characteristics: the name of the auction house, date of auction, reserve price and transaction price. The list of artists included in the research sample and descriptive statistics of artworks by artists is shown in Table 2.

Table 2 presents the summary of statistics of the characteristics of sold paintings by 30 artists, including the reference artist. The average price ranges from the lowest of PLN21,714, PLN23,193 and PLN26,847 paid for the artworks of Hofman, Stryjeńska and Weiss, respectively, to the highest of PLN368,588, PLN328,333 and PLN202,176 for the paintings of Brandt, Chełmoński and Zak, respectively.

Standard deviations of prices vary from PLN15,993 to PLN449,849. On the basis of the foregoing, one may say that prices of artworks by Stryjeńska, Axentowicz and Stanisławski are less variable with the lowest standard deviations of PLN15,993, PLN17,590 and PLN18,150, respectively. It is confirmed by the lowest value of coefficient of variation (not shown in Table 2) measuring the standard deviation relative to the mean. The prices of artworks by Chełmoński, Brandt and Kowalski-Wierusz (the first two with the highest average price) show the highest volatility with standard deviation of PLN449,849, PLN382,662 and PLN273,400, respectively. The coefficients of variation indicate that prices of Gierowski, Wyczółkowski and KowalskiWierusz are most variable.

Distribution properties of the price seem to be abnormal. The peakedness of the price distribution measured by kurtosis is negative for five artists ranging from -1.16 (Pagowska) to -0.48 (Muter), which indicates a wide and flattened distribution. The kurtosis for all other painters is greater than 0, varying from 0.09 (Tarasin) to 33.14 (Fałat) suggesting a sharper peak and longer tail than in a normal distribution. The measures of skewness are all positive and vary from 0.31 (Stanisławski) to 5.27 (Fałat). It suggests that a sampling distribution of skewness is asymmetrical with a longer upper tail of prices. The calculated Jarque-Bera statistics [6.5; 1456.9] and $p$-values $(<0.01$; not shown in Table 2) confirm that the prices are not approximated by a normal distribution.

\section{Empirical Results}

The need to define the return on paintings on the Polish auction market implies the use of a procedure of hedonic price index calculation. This procedure is a three-step one: (a) estimation of hedonic regression model (1); (b) use of estimated regression coefficients to evaluate the hedonic quality adjustment (3), and (c) calculation of the hedonic price 
Table 2 Descriptive statistics of artworks by artist

\begin{tabular}{|c|c|c|c|c|c|c|c|}
\hline Artist and variable name & Born & Died & $\begin{array}{l}\text { Works } \\
\text { sold }\end{array}$ & Mean & $\begin{array}{l}\text { Std. } \\
\text { deviation }\end{array}$ & Kurtosis & Skewness \\
\hline AXENTOWICZ Teodor, AXE & 1859 & 1938 & 56 & 31,371 & 17,590 & 8.77 & 2.38 \\
\hline BOZNAŃSKA Olga, BOZ & 1865 & 1940 & 16 & 181,969 & 269,537 & 12.92 & 3.48 \\
\hline BRANDT Józef, BRA & 1841 & 1915 & 17 & 368,588 & 382,662 & -0.74 & 0.86 \\
\hline CHEŁMOŃSKI Józef, CHŁ & 1849 & 1914 & 18 & 328,333 & 449,849 & 2.51 & 1.74 \\
\hline DUDA-GRACZ Jerzy, DDG & 1941 & 2004 & 46 & 32,670 & 21,428 & 1.17 & 1.14 \\
\hline FAŁAT Julian, FAŁ & 1853 & 1929 & 66 & 38,808 & 56,342 & 33.14 & 5.27 \\
\hline GIEROWSKI Stefan, GER & 1925 & - & 43 & 34,160 & 82,696 & 19.00 & 4.08 \\
\hline HAYDEN Henryk, HAY & 1883 & 1970 & 35 & 62,406 & 94,182 & 7.89 & 2.80 \\
\hline $\begin{array}{l}\text { HOFMAN Vlastimil, reference variable } \\
\text { HOF }\end{array}$ & 1881 & 1970 & 128 & 21,714 & 18,988 & 15.11 & 3.15 \\
\hline KANELBA Rajmund, KNB & 1897 & 1960 & 59 & 27,761 & 22,083 & 3.73 & 1.91 \\
\hline KANTOR Tadeusz, KTR & 1915 & 1990 & 42 & 55,619 & 75,200 & 2.37 & 1.69 \\
\hline KOSSAK Juliusz, KJU & 1824 & 1899 & 45 & 53,388 & 70,161 & 7.77 & 2.68 \\
\hline KOSSAK Wojciech, KWO & 1856 & 1942 & 77 & 35,019 & 36,776 & 15.53 & 3.24 \\
\hline KOWALSKI Alfred, KWR & 1849 & 1915 & 25 & 180,880 & 273,400 & 15.39 & 3.72 \\
\hline LEBENSTEIN Jan, LEB & 1930 & 1999 & 45 & 35,191 & 46,129 & 4.97 & 2.10 \\
\hline MALCZEWSKI Jacek, MAJ & 1854 & 1929 & 88 & 117,608 & 145,669 & 1.28 & 1.47 \\
\hline MENKES Zygmunt, MEN & 1896 & 1986 & 63 & 57,948 & 42,680 & 4.27 & 1.76 \\
\hline MUTER Mela, MUT & 1876 & 1967 & 61 & 113,725 & 68,820 & -0.48 & 0.47 \\
\hline NOWOSIELSKI Jerzy, NOW & 1923 & 2011 & 117 & 72,050 & 66,890 & 0.42 & 1.00 \\
\hline PANKIEWICZ Józef, PAN & 1866 & 1940 & 35 & 109,071 & 68,417 & 6.21 & 2.15 \\
\hline PĄGOWSKA Teresa, PĄG & 1929 & 2007 & 34 & 38,141 & 33,280 & -1.16 & 0.64 \\
\hline STANISŁAWSKI Jan, STN & 1860 & 1907 & 29 & 44,862 & 18,150 & -0.84 & 0.31 \\
\hline STAŻEWSKI Henryk, STŻ & 1894 & 1988 & 53 & 27,691 & 28,047 & 16.24 & 3.41 \\
\hline STRYJEŃSKA Zofia, STR & 1894 & 1976 & 65 & 23,193 & 15,993 & -0.62 & 0.47 \\
\hline TARASIN Jan, TAR & 1926 & 2009 & 82 & 30,341 & 31,890 & 0.09 & 1.08 \\
\hline TRUSZ Iwan, TRU & 1869 & 1940 & 71 & 36,782 & 32,663 & 5.94 & 2.32 \\
\hline WEISS Wojciech, WEI & 1875 & 1950 & 81 & 26,847 & 18,561 & 1.04 & 0.99 \\
\hline WITKACY, WTK & 1885 & 1939 & 81 & 45,852 & 34,508 & 8.90 & 2.92 \\
\hline WYCZÓŁKOWSKI Leon, WCZ & 1852 & 1936 & 119 & 59,472 & 99,844 & 12.78 & 3.51 \\
\hline ZAK Eugeniusz, ZAK & 1884 & 1926 & 17 & 202,176 & 171,261 & 0.13 & 1.04 \\
\hline
\end{tabular}

Source: My own study

index according to the formula (2). The results of hedonic ordinary least squares (OLS) regression analysis are presented in Table 3 . The adjusted $\mathrm{R}^{2}$ of 0.6641 is sufficient for cross-sectional data. The value of the F-statistic equals 54.26, which indicates that the regression equation correctly maps the relationship between the independent variables and the dependent variable.

Explanatory variables reflecting personal characteristics of the artist comprise the name of an artist and living status $(D T H)$. Most artist variable coefficients are significant at the 
Table 3 Estimated coefficients, standard errors and levels of significance for the hedonic regression model

\begin{tabular}{|c|c|c|c|c|c|c|c|}
\hline Variable & $\begin{array}{l}\text { Estimated } \\
\text { Coeff. }\end{array}$ & $\begin{array}{l}\text { Standard } \\
\text { Error }\end{array}$ & $\begin{array}{l}\text { Level of } \\
\text { Signific. }\end{array}$ & Variable & $\begin{array}{l}\text { Estimated } \\
\text { Coeff. }\end{array}$ & $\begin{array}{l}\text { Standard } \\
\text { Error }\end{array}$ & $\begin{array}{l}\text { Level of } \\
\text { Signific. }\end{array}$ \\
\hline$\alpha_{0}$ & 8.0892 & 0.1741 & & WATERCOLOR & -0.2864 & 0.0662 & $* * *$ \\
\hline AXE & 1.2237 & 0.1203 & $* * *$ & OIL & 1.0056 & 0.0583 & $* * *$ \\
\hline $\mathrm{BOZ}$ & 1.7140 & 0.1825 & $* * *$ & SURFACE & 1.2470 & 0.0499 & $* * *$ \\
\hline BRA & 2.0937 & 0.1790 & $* * *$ & AHAGRA & 0.1281 & 0.0542 & $* *$ \\
\hline $\mathrm{CHE}$ & 1.8626 & 0.1741 & $* * *$ & AHDESA & 0.1563 & 0.0579 & $* * *$ \\
\hline DDG & 0.3727 & 0.1192 & $* * *$ & AHPOLSWISS & 0.5363 & 0.0684 & $* * *$ \\
\hline FAt & 1.5225 & 0.1178 & $* * *$ & AHREMPEX & 0.0497 & 0.0533 & \\
\hline GER & 0.1148 & 0.1308 & & 2007Q2 & 0.0560 & 0.1161 & \\
\hline HAY & 0.5972 & 0.1327 & $* * *$ & 2007Q3 & 0.2057 & 0.1670 & \\
\hline $\mathrm{KNB}$ & 0.2869 & 0.1109 & $* * *$ & 2007Q4 & 0.1931 & 0.1123 & $*$ \\
\hline KTR & 0.4859 & 0.1287 & $* * *$ & 2008Q1 & 0.4028 & 0.1225 & $* * *$ \\
\hline KJU & 1.8907 & 0.1334 & $* * *$ & 2008Q2 & 0.3537 & 0.1152 & $* * *$ \\
\hline KWO & 0.1788 & 0.1000 & $*$ & 2008Q3 & 0.1500 & 0.1587 & \\
\hline KWR & 1.7587 & 0.1515 & $* * *$ & 2008Q4 & 0.3564 & 0.1088 & $* * *$ \\
\hline LEB & 0.3811 & 0.1261 & $* * *$ & 2009Q1 & 0.2044 & 0.1230 & $*$ \\
\hline MAJ & 1.2860 & 0.0970 & $* * *$ & 2009Q2 & 0.2835 & 0.1269 & $* *$ \\
\hline MEN & 0.8568 & 0.1086 & $* * *$ & 2009Q3 & 0.1543 & 0.1399 & \\
\hline MUT & 1.5816 & 0.1093 & $* * *$ & 2009Q4 & 0.1926 & 0.1128 & $*$ \\
\hline NOW & 1.1102 & 0.1337 & $* * *$ & 2010Q1 & 0.0499 & 0.1312 & \\
\hline PAN & 1.7502 & 0.1317 & $* * *$ & 2010Q2 & -0.1159 & 0.1299 & \\
\hline PĄG & 0.0318 & 0.1413 & & 2010Q3 & 0.0034 & 0.1723 & \\
\hline STN & 1.2555 & 0.1420 & $* * *$ & 2010Q4 & -0.0310 & 0.1256 & \\
\hline STŻ & 0.9947 & 0.1231 & $* * *$ & 2011Q1 & 0.2066 & 0.1539 & \\
\hline STR & 0.7843 & 0.1210 & $* * *$ & 2011Q2 & -0.3296 & 0.1762 & \\
\hline TAR & 0.2497 & 0.1359 & $*$ & 2011Q3 & 0.1349 & 0.1306 & \\
\hline TRU & 0.5780 & 0.1020 & $* * *$ & 2011Q4 & 0.1327 & 0.1409 & \\
\hline WEI & 0.3900 & 0.0996 & $* * *$ & 2012Q1 & -0.0255 & 0.1215 & \\
\hline WTK & 1.7270 & 0.1140 & $* * *$ & 2012Q2 & 0.0765 & 0.1826 & \\
\hline WCZ & 1.8774 & 0.0973 & $* * *$ & 2012Q3 & -0.0670 & 0.1445 & $*$ \\
\hline ZAK & 2.4142 & 0.1812 & $* * *$ & 2012Q4 & 0.0192 & 0.1286 & \\
\hline DTH & 0.0808 & 0.1243 & & & & & \\
\hline
\end{tabular}

Source: My own study

***,*** indicate significance at the 10,5 and $1 \%$ significance level $\mathrm{R}^{2}$ : 0.6641; F: 54.26; degrees of freedom: 1647

level of $1 \%$, which may be interpreted as the influence of the name of the painter on the price of an artwork. According to the estimated coefficients for this variable, this influence is positive since Hofman's artworks, as $H O F$ is the reference variable, are cheapest on average. The living status of the artist 
$(D T H)$ seems to be statistically insignificant indicating that it does not matter for the market whether the artist is alive.

The second set of explanatory variables reflects physical attributes of an artwork, i.e. a medium and a surface. According to the first one, a technique used to produce the artwork influences the price significantly. This influence is positive for the works produced in oil $(O I L)$ as their long lasting physical quality is likely to fetch higher prices, and negative for the works painted in watercolor (WATERCOLOR). The works in oil seem to be more appreciated and the works in watercolor seem to be less appreciated than other media (reference category). The size coefficient of the variable, i.e. SURFACE, indicates that art prices tend to increase with size and this relationship is significant.

Table 4 Nominal quarterly art indices and changes according to the previous year in Poland, United Kingdom and France

\begin{tabular}{|c|c|c|c|c|c|c|c|c|c|}
\hline \multirow[t]{2}{*}{ QUARTER } & \multicolumn{3}{|c|}{$\begin{array}{l}\text { Price index for basic period }= \\
\text { previous year }\end{array}$} & \multicolumn{3}{|c|}{$\begin{array}{l}\text { Changes [in \%] according } \\
\text { to previous year }\end{array}$} & \multicolumn{3}{|c|}{$\begin{array}{l}\text { Quarterly rates of return } \\
\text { [in \%] }\end{array}$} \\
\hline & $\begin{array}{l}\text { PL } \\
\text { (in PLN) }\end{array}$ & $\begin{array}{l}\mathrm{UK} \\
\text { (in GBP) }\end{array}$ & $\begin{array}{l}\text { France } \\
\text { (in EUR) }\end{array}$ & PL & UK & France & PL & UK & France \\
\hline 2007Q1 & 1.0000 & 1.1036 & 1.0386 & 0.00 & 10.36 & 3.86 & - & 10.36 & 3.86 \\
\hline 2007Q2 & 1.3308 & 0.9895 & 1.0185 & $3 ., 08$ & 1.05 & 1.85 & 33.08 & -1.05 & 1.85 \\
\hline 2007Q3 & 1.3000 & 0.9958 & 1.0383 & $3 ., 00$ & -0.42 & 3.83 & 30.00 & -0.42 & 3.83 \\
\hline 2007Q4 & 1.9066 & 1.0870 & 1.0067 & $9 ., 66$ & 8.70 & 0.67 & 90.66 & 8.70 & 0.67 \\
\hline 2008Q1 & 1.2758 & 1.0554 & 0.9711 & $2 ., 58$ & 5.54 & -2.89 & 27.58 & 5.54 & -2.89 \\
\hline 2008Q2 & 0.8804 & 0.9200 & 0.9891 & $-1 ., 96$ & -8.00 & -1.09 & -11.96 & -8.00 & -1.09 \\
\hline 2008Q3 & 0.8594 & 0.8699 & 0.9564 & $-1 ., 06$ & -13.01 & -4.36 & -14.06 & -13.01 & -4.36 \\
\hline 2008Q4 & 1.2927 & 0.9286 & 0.9025 & 2,27 & -7.14 & -9.75 & 29.27 & -7.14 & -9.75 \\
\hline 2009Q1 & 0.7346 & 1.0052 & 0.9491 & -26.54 & 0.52 & -5.09 & -26.54 & 0.52 & -5.09 \\
\hline 2009Q2 & 0.8887 & 0.9846 & 0.9772 & -11.13 & -1.54 & -2.28 & -11.13 & -1.54 & -2.28 \\
\hline 2009Q3 & 0.7252 & 0.9822 & 0.9696 & -27.48 & -1.78 & -3.04 & -27.48 & -1.78 & -3.04 \\
\hline 2009Q4 & 1.9224 & 1.0651 & 1.0192 & 92.24 & 6.51 & 1.92 & 92.24 & 6.51 & 1.92 \\
\hline 2010Q1 & 0.6421 & 1.0903 & 1.0240 & -35.79 & 9.03 & 2.40 & -35.79 & 9.03 & 2.40 \\
\hline 2010Q2 & 0.8984 & 1.0295 & 1.0522 & -10.16 & 2.95 & 5.22 & -10.16 & 2.95 & 5.22 \\
\hline 2010Q3 & 0.7908 & 0.9903 & 1.0440 & -20.92 & -0.97 & 4.40 & -20.92 & -0.97 & 4.40 \\
\hline 2010Q4 & 1.2841 & 1.0490 & 0.9748 & 28.41 & 4.90 & -2.52 & 28.41 & 4.90 & -2.52 \\
\hline 2011Q1 & 1.0083 & 1.0417 & 0.9774 & 0.83 & 4.17 & -2.26 & 0.83 & 4.17 & -2.26 \\
\hline 2011Q2 & 0.8517 & 0.9549 & 0.9822 & -14.83 & -4.51 & -1.78 & -14.83 & -4.51 & -1.78 \\
\hline 2011Q3 & 0.8791 & 0.9452 & 0.9836 & -12.09 & -5.48 & -1.64 & -12.09 & -5.48 & -1.64 \\
\hline 2011Q4 & 1.6256 & 1.0158 & 0.9945 & 62.56 & 1.58 & -0.55 & 62.56 & 1.58 & -0.55 \\
\hline 2012Q1 & 1.1511 & 1.0568 & 0.9746 & 15.11 & 5.68 & -2.54 & 15.11 & 5.68 & -2.54 \\
\hline 2012Q2 & 0.9816 & 0.9922 & 0.9811 & -1.84 & -0.78 & -1.89 & -1.84 & -0.78 & -1.89 \\
\hline 2012Q3 & 0.2701 & 0.9391 & 1.0075 & -72.99 & -6.09 & 0.75 & -72.99 & -6.09 & 0.75 \\
\hline 2012Q4 & 4.4053 & 1.0622 & 1.0183 & 340.53 & 6.22 & 1.83 & 340.53 & 6.22 & 1.83 \\
\hline
\end{tabular}


The final set of variables relates to the sale characteristics, i.e. the auction house and the quarter and year of sale. In most cases (except REMPEX) auction houses have a positive and significant impact on prices of artworks. Most of the time variables are insignificant. Some of them indicate the relationship between the year and quarter of sale and the price. It is suggested that, in comparison to 2007 quarter one as the reference variable, 2010 quarters two and four, 2011 quarter two, and 2012 quarters one and three, possibly lowered the prices of sold artworks, while the remaining quarters were likely to increase the prices.

The parameter estimates of the model (1) were used to evaluate hedonic quality adjustments (3) and hedonic price indices (2). The hedonic price indices for the Polish art market are of the chain type and were calculated on the basis of the first quarter of 2007, while single based art indices for French and British art markets were obtained on the basis of July 1990 and were transformed into the chain type. Thus, nominal quarterly art indices and changes according to the previous year are shown in the Table 4.

Analyzing quarterly rates of return, great changes in prices on the Polish art market in the investigated period are observed, i.e. the essential return rate of $340.53 \%$ in 2012 quarter four, $92.24 \%$ in 2009 quarter four, $90.66 \%$ in 2007 quarter four, and negative returns of $-72.99 \%$ in 2012 quarter three, $-35.79 \%$ in 2010 quarter one and $-26.26 \%$ in 2009 quarter one. The standard deviation for quarterly return rates on the Polish art market is $83.67 \%$. The returns on French and British markets are quite low in comparison with Polish ones. French and British art markets experienced a slump in 2008 with the highest negative returns in the United Kingdom for the quarters two, three and four $(-8.0,-13.01$ and $-7.14 \%$, respectively) and a recovery beginning from 2010 with moderate and moderately volatile returns [-5.48; 9.03]. In France, the highest negative returns occurred in 2008 quarter four $(-9.75 \%)$ and 2009 quarter one $(-5.09 \%)$. The biggest recovery was observed in 2010 quarter two with the return of $5.22 \%$ and in 2010 quarter three with the return of $4.4 \%$. Quarterly rates of return on British and French art markets are more stable with a standard deviation of 6.05 and 3.34 , respectively.

Table 5 Average changes and rates of return in Poland, the United Kingdom and France

\begin{tabular}{|c|c|c|c|c|c|c|}
\hline \multirow[t]{2}{*}{ Year } & \multicolumn{3}{|c|}{ Average annual changes } & \multicolumn{3}{|c|}{ Annual rates of return [in \%] } \\
\hline & Poland & UK & France & Poland & UK & France \\
\hline 2007 & - & 1.0427 & 1.0255 & - & 4.27 & 2.55 \\
\hline 2008 & 1.0569 & 0.9411 & 0.9542 & 5.69 & -5.89 & -4.58 \\
\hline 2009 & 0.9767 & 1.0087 & 0.9784 & -2.33 & 0.87 & -2.16 \\
\hline 2010 & 0.8749 & 1.0391 & 1.0233 & -1.51 & 3.91 & 2.33 \\
\hline 2011 & 1.0525 & 0.9886 & 0.9844 & 5.25 & -1.14 & -1.56 \\
\hline 2012 & 1.0768 & 1.0113 & 0.9952 & 7.68 & 1.13 & -0.48 \\
\hline \multicolumn{4}{|c|}{$2007-2012$} & 5.51 & 0.47 & -0.68 \\
\hline \multicolumn{4}{|c|}{ standard deviation } & 8.34 & 3.74 & 2.74 \\
\hline
\end{tabular}

Source: My own study 
Having evaluated price indices for the Polish art market and using indices for British and French art markets, one may make a calculation of average annual changes and returns (Table 5). Investments in Polish paintings in the period 2008-2012 brought a profit at a high average level of $5.51 \%$, while the financial results on British and French art markets were less satisfactory, reaching 0.47 and $-0.68 \%$, respectively. On the other hand, financial results on the Polish market are much more unstable, ranging from $-2.33 \%$ in 2009 to $7.68 \%$ in 2012 with a standard deviation of $8.34 \%$. The British and French art markets in 2007-2012 demonstrated results ranging from $-5.89 \%$ in 2008 to $3.91 \%$ in 2010 and from $-4.58 \%$ in 2008 to $2.33 \%$ in 2010 , respectively. The standard deviation of annual rates of return was also much lower than in case of the Polish art market (about 3.74 and $2.74 \%$, respectively), which shows a greater stability of these markets.

\section{Summary}

This study was designed to construct a quarterly Polish art price index. It allows us to make a comparison with the annual performance of other art markets (i.e. British and French). The hedonic price is used to construct this index with the use of 1708 auction records of the 30 most important Polish painters. The data were obtained from Polish auction houses and covered the period 2007-2012. The hedonic price equation has proved that there are some features of the artwork that are associated with a higher price, i.e. the name of an artist (Brandt, Juliusz Kossak and Zak), oil as a medium, large surface and sale in the Polswiss Art auction house.

The plots of rates of return on art markets in the United Kingdom and France corresponded closely to one another facing the downturn in 2008 to $-5.89 \%$ and $-4.58 \%$, respectively, and later a weak increase. In Poland, declines in 2009 to $-2.33 \%$ and 2010 to $-1.51 \%$ suffered with some delay as compared to the United Kingdom and France. The recovery of the Polish art market was substantial to $5.25 \%$ in 2011 and $7.68 \%$ in 2012.

British and French stable rates of return and standard deviations remain in opposition to Polish strongly volatile ones. The Polish art index and return on the art market remain unstable, strongly volatile, responding with some delay as compared to other European art markets. It might be an investment opportunity, which could be considered by more risky investors.

Acknowledgments This article is a part of a research project NCN 2012/05/B/HS4/04188 "Investing in Paintings on the Financial Market" funded by the National Science Centre in Krakow.

Open Access This article is distributed under the terms of the Creative Commons Attribution License which permits any use, distribution, and reproduction in any medium, provided the original author(s) and the source are credited.

\section{References}

Agnello, R. J. (2002). Investment returns and risk for art: evidence from auctions of American paintings. Eastern Economic Journal, 28(4), 443-463. 
Agnello, R. J., \& Pierce, R. K. (1996). Financial returns, price determinants, and genre effects in American art investment. Journal of Cultural Economics, 20(4), 359-383.

Agnello R. J., Xu X.; 2008; Prices for Paintings by African American Artists and Their Contemporaries: Does Race Matter?; Working Papers University of Delaware, Department of Economics; No. 08-06; available at: http:/graduate.lerner.udel.edu/sites/default/files/ECON/PDFs/RePEc/dlw/WorkingPapers/2008/ UDWP2008-06.pdf; 1-28.

Barbosa, R. L., \& Campos, N. F. (2008). Paintings and numbers: an econometric investigation of sales rates, prices and returns in latin American art Auctions. IZA Discussion Paper Series, 3445, 35-37.

Biey, M., \& Zanola, R. (2005). The market for picasso prints: a hybrid model approach. Journal of Cultural Economics, 29(2), 127-136.

Buelens, N., \& Ginsburgh, V. (1993). Revisiting Baumol's 'Art as floating crap game. European Economic Review, 37(7), 1351-1371.

Chanel, O., Gérard-Varet, L., \& Ginsburgh, V. (1996). The relevance of hedonic price indices. Journal of Cultural Economics, 20(1), 1-24.

Czujack, C. (1997). Picasso paintings at auction, 1963-1994. Journal of Cultural Economics, 21(3), $229-247$.

De la Barre, M., Doccio, S., \& Ginsburgh, V. (1994). Returns on impressionist, modern and contemporary European paintings, 1962-1991. Annales d'Economie et Statistique, 35, 143-181.

Dürr F.; 2010; The Swiss Art Index; Master Thesis, Lucerne University of Applied Sciences and Arts, School of Management and Law, available at: http:/www.zhaw.ch/fileadmin/php_includes/popup/hop-etail.php? hop id=409376712; 17-23.

Edwards S.; 2004; The Economics of Latin American Art: Creativity Patterns and Rates of Return; NBER Working Papers, Working Paper 10302, available at: http://www.nber.org/papers/w10302; 11-14.

Forte F., Mantovani M.; 2004; Manuale di economia e politica dei beni culturali; Rubbettino Editore; Soveria Mannelli; Italy.

Gajewski M., Potocki T.; 2013; Skate's Focus Poland's Art Market: The Rising Star of Central Europe; Skate's Art Market Research Art \& Business Magazine S.A., Skate's, LLC, New York, USA, available at: http:// skatesart.files.wordpress.com/2013/03/skates-focus-polands-art-market.pdf.; 6-8.

Hausner J., Karwińska A., Purchla J.; 2013; Kultura a rozwój; Narodowe Centrum Kultury; Warsaw; Poland (in Polish).

Higgs, H. (2012). Australian art market prices during the global financial crisis and two earlier decades. Australian Economic Papers, 51(4), 189-209.

Hodgson, D. (2011). An analysis of pricing and returns in the market for French Canadian paintings. Applied Economics, 43, 63-73.

Hodgson, D. J., \& Vorkink, K. P. (2004). Asset pricing theory and the valuation of Canadian paintings. Canadian Journal of Economics, 37(3), 629-655.

Kraeussl R., Logher R.; 2010; Emerging art markets; Emerging Markets Review; Vol. 11, No. 4, available at: http://ssrn.com/abstract=1304856; 4-6.

Kräussl R., Elsland N.; 2008; Constructing the true art market index: A novel 2-step hedonic approach and its application to the German art market; Center for Financial Studies Working Paper, No. 2008/11, available at: http://hdl.handle.net/10419/25546; 1-31.

Kräussl R., Schellart E.; 2007; Hedonic Pricing of Artworks: Evidence from German Paintings; Working Paper, VU University Amsterdam, available at: http://ssrn.com/abstract=968198; 8-20.

Lucińska A.; 2011; Malarstwo na polskim rynku aukcyjnym; Kalinowski M. (ed): Rynki finansowe. Nowe wyzwania i możliwości; Prace Naukowe Wyższej Szkoły Bankowej w Gdańsku; Tom 11; CeDeWu; Warsaw, Poland, 239-250 (in Polish).

Renneboog L., Spaenjers C.; 2013; Buying Beauty: On Prices and Returns in the Art Market; Management Science; Vol. 59, No. 1, available at: http://ssrn.com/abstract=1352363; 5-20.

Renneboog, L., \& van Houtte, T. (2002). The monetary appreciation of paintings: from realism to magritte. Cambridge Journal of Economics, 26(3), 311-357.

Sokołowska E.; 2012; Ewolucja i perspektywy rozwoju art investment jako alternatywnej formy inwestowania; Piłatowska M. (ed.) Ekonometria dla praktyki; Polskie Towarzystwo Ekonomiczne Oddział w Toruniu; Toruń; Poland (in Polish);159 - 175.

Throsby D.; 2010; Ekonomia i kultura; Narodowe Centrum Kultury; Warsaw; Poland (in Polish).

Towse R.; 2011; Ekonomia kultury. Kompendium; Narodowe Centrum Kultury; Warsaw; Poland (in Polish).

Triplett J.E.; 2006; Handbook on Hedonic Indexes and Quality Adjustments in Price Indexes; OECD; Paris; France; 63.

Worthington, A., \& Higgs, H. (2006). A note on financial risk, return and asset pricing in Australian modern and contemporary art. Journal of Cultural Economics, 30(1), 73-87. 